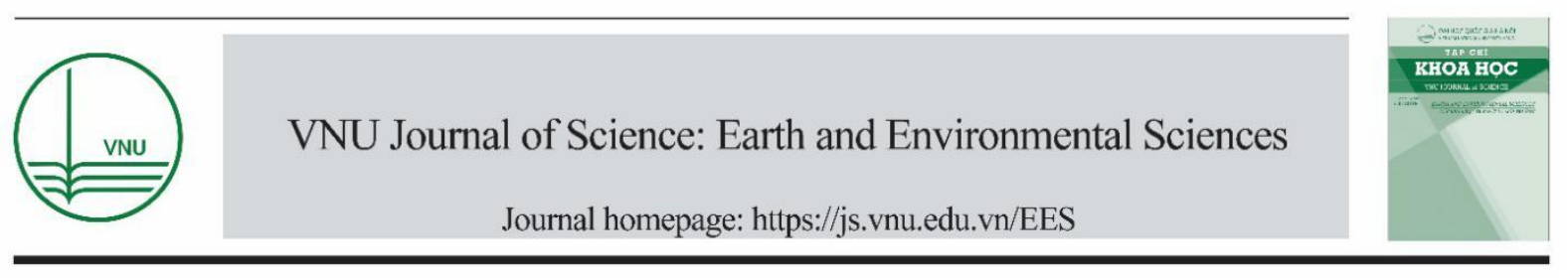

\title{
Original Article \\ Assessments of Sand Dune Ecosystem Service Potential from Son Tra (Da Nang) to Tam Ky (Quang Nam)
}

\author{
Dang Kinh Bac*, Dang Van Bao, Dang Thi Thanh Hang, Ngo Chi Cuong \\ VNU University of Science, 334 Nguyen Trai, Hanoi, Vietnam
}

Received 05 June 2020

Revised 17 August 2020; Accepted 28 August 2020

\begin{abstract}
The coastal area in the Son Tra - Tam Ky region have various kinds of sand dunes: (1) embryo dunes; (2) foredunes; (3) yellow dunes; (4) gray dunes; (5) white dunes; (6) brown dunes. These sand dunes play an important role in maintaining biodiversity, minimizing the damage of natural hazards and tourism development. In last decade, the sand dunes in Son Tra (Da Nang) Tam Ky (Quang Nam) is strongly influenced by urbanization and tourism development. Different resorts have been built along the beaches, narrowing protective forests on the sand dunes. It does not only reduce the value of cultural ecosystem services; but also, the ability to regulate natural disasters and air pollution. Therefore, the study aims to assess the unbalance in sand dune ecosystems service supply in Son Tra - Tam Ky area. Methods used in the study include: remote sensing and GIS, collecting statistics and specialist interviews. The results showed a clear differentiation in the potential of the ecosystem services in different sand dune types. Lastly, the study analyzed the values of sand dune ecosystem services in Son Tra - Cua Dai part; to assess differences in planning and development policies between the coastal zones of Quang Nam and Da Nang.
\end{abstract}

Keywords: Ecosystem service matrix, embryo dune, foredune, expert judgment, land use/cover.

\footnotetext{
* Corresponding author.

E-mail address: dangkinhbac@hus.edu.vn
}

https://doi.org/10.25073/2588-1094/vnuees.4645 


\title{
Đánh giá tiềm năng cung cấp dịch vụ hệ sinh thái đụn cát ven biển khu vực Sơn Trà (Đà Nẵng) - Tam Kỳ (Quảng Nam)
}

\author{
Đặng Kinh Bắc* , Đặng Văn Bào, Đặng Thị Thanh Hằng, Ngô Chí Cường \\ Truòng Đại học Khoa học Tụ nhiên, Đại học Quốc gia Hà Nội, 334 Nguyễn Trãi, Hà Nội, Việt Nam
}

Nhận ngày 05 tháng 6 năm 2020

Chỉnh sửa ngày 17 tháng 8 năm 2020; Chấp nhận đăng ngày 28 tháng 8 năm 2020

\begin{abstract}
Tóm tắt: Dải ven biển Sơn Trà - Tam Kỳ phân bố khá phổ biến các đụn cát biển từ trẻ đến trưởng thành: i) đụn cát phôi thai; ii) đụn cát tiền tiêu; iii) đụn cát vàng; iv) đụn cát xám; v) đụn cát trắng; vi) đụn cát nâu. Hệ thống đụn cát ven biển này góp phần tạo nên các hệ sinh thái có vai trò quan trọng trong bảo vệ đa dạng sinh học, phòng tránh thiên tai, phát triển du lịch. Trong những năm gần đây, các hệ sinh thái đụn cát từ Sơn Trà đến Tam Kỳ đã và đang chịu ảnh hưởng mạnh bởi quá trình đô thị hóa và phát triển du lịch, một không gian khá lớn rừng phòng hộ trên các đụn cát ven biển đã bị phá hủy. Điều này không những làm giảm giá trị dịch vụ văn hóa cuả hệ sinh thái mà còn làm giảm khả năng điều tiết các tai biến thiên nhiên và ô nhiễm không khí ven biển. Nghiên cứu này hướng tới làm rõ thực trạng mất cân bằng trong điều phối dịch vụ hệ sinh thái (DVHST) đụn cát ven biển khu vực Sơn Trà - Tam Kỳ. Phương pháp sử dụng trong nghiên cứu gồm: viễn thám và GIS, thu thập số liệu thống kê và tham vấn chuyên gia đa ngành. Kết quả nghiên cứu cho thấy có sự phân hóa rõ rệt về tiềm năng cung cấp DVHST đụn cát ven biển. Nghiên cứu tập trung hơn vào sự phân bố giá trị từng loại hình DVHST dọc ven biển Sơn Trà - Cửa Đại, nhằm đánh giá sự khác biệt trong định hướng quy hoạch và phát triển vùng đụn cát ven biển Quảng Nam và Đà Nẵng.
\end{abstract}

Tù̀ khóa: Ma trận dịch vụ hệ sinh thái, đụn cát phôi thai, đụn cát tiền tiêu, tham vấn chuyên gia, lớp phủ.

\section{Mở đầu}

Đụn cát ven biển là một thành tạo tự nhiên không thể tách rời của đới bờ biển và là dạng cảnh quan phổ biến của dải ven biển trên toàn thế giới. Việt Nam là quốc gia ven biển với đường bờ trải dài trên $3.260 \mathrm{~km}$ với sự đa dạng của cảnh quan và hệ sinh thái, trong đó hệ sinh thái đụn cát tập trung chủ yếu ở dải ven biển miền Trung. Dải ven biển từ Sơn Trà (Đà Nẵng) đến Tam Kỳ (Quảng Nam) là nơi có mặt đầy đủ của hệ thống đụn cát từ trẻ cho đến trưởng thành, đã tạo nên hệ sinh thái đụn cát đặc trưng cho vùng. Tùy thuộc vào độ cao, chiều rộng, hình thái và trạng thái sinh thái của các đụn cát mà chúng có giá trị khác nhau trong bảo vệ con người và cơ sở hạ tầng ven biển khỏi các mối nguy cơ tự nhiên như lũ lụt ven biển, tác động của sóng, nước dâng do bão, giúp giảm thiểu xói lở bờ biển, biến đổi khí hậu, nước biển dâng và xâm nhập mặn.

Mặc dù hệ thống đụn cát có tầm quan trọng đặc biệt đối với việc bảo vệ con người và bờ biển, song trong những năm gần đây, chúng đang chịu áp lực nghiêm trọng do quá trình đô thị hóa, phát triển du lịch, khai thác cát, mở rộng nông nghiệp và phát triển nuôi trồng thủy sản trên cát. Những hoạt động này dẫn đến các hình thức suy thoái khác nhau như các đụn cát bị phân nhỏ, ngắt đoạn, ô nhiễm môi trường, mất nơi sinh sống của

\footnotetext{
* Tác giả liên hệ.

Địa chỉ email: dangkinhbac@ hus.edu.vn

https://doi.org/10.25073/2588-1094/vnuees.4645
} 
một số loài thực động vật [1]. Nhằm góp phần bảo vệ và duy trì giá trị dịch vụ hệ sinh thái đụn cát ven biển, nghiên cứu này hướng tới việc phân tích tiềm năng cung cấp dịch vụ hệ sinh thái (DVHST) trên các dạng địa hình đụn cát, làm cơ sở cho quản lý bờ biển Sơn Trà - Tam Kỳ.

Nghiên cứu tập trung vào hệ thống đụn cát phân bố dọc theo ven biển từ phía nam Sơn Trà đến thành phố Tam Kỳ. Ranh giới khu vực nghiên cứu được giới hạn về phía biển là đường bờ trong (đường ranh giới thảm thực vật tự nhiên) và giới hạn trong là điểm cuối cùng phát hiện các thành tạo đụn cát tuổi Pleistocen. Nhằm đạt được mục tiêu đặt ra, nhóm tác giả sẽ phân tích đặc điểm địa mạo và quy luật phân bố các đụn cát tại khu vực nghiên cứu; đánh giá giá trị DVHST trên các địa mạo đụn cát; từ đó đưa ra những nhận xét, luận giải về quá trình tiến hóa đụn cát, xu thế biến đồi sử dụng đất trên các đụn cát trong quá khứ, hiện tại và tương lai.

\section{Dịch vụ hệ sinh thái đụn cát ven biển Sơn Trà - Tam Kỳ}

\subsection{Khái niệm và phân loại dịch vụ hệ sinh thái đụn cát}

Dịch vụ hệ sinh thái đã được các nhà khoa học trên thế giới quan tâm nghiên cứu từ lâu, song ở Việt Nam chưa thực sự phát triển. Báo cáo đánh giá hệ sinh thái thiên niên kỷ đã định nghĩa DVHST là những lợi ích thu nhận được từ các hệ sinh thái [2]. Theo định nghĩa này, đánh giá DVHST đụn cát là phân tích những lợi ích của các hệ sinh thái phát triển trên các đụn cát tự nhiên, giúp con người tồn tại và phát triển. Những lợi ích này đến từ ba hình thức vốn khác nhau, bao gồm vốn từ xã hội, con người và xây dựng [3]. Vốn tự nhiên đề cập đến khả năng vốn có của các hệ sinh thái đụn cát để cung cấp DVHST, không bao gồm những đóng góp từ các hoạt động con người. Trong khi đó, đầu vào của vốn xã hội là con người để tối ưu hóa nguồn cung của DVHST đụn cát. Các lợi ích liên quan có thể được hữu dụng, không hữu dụng, giới hạn hoặc không tùy thuộc vào loại DVHST đụn cát. Các

\footnotetext{
${ }^{1}$ https://www.millenniumassessment.org/en/
}

nhà khoa học trên thế giới cơ bản thống nhất phân chia DVHST ra ba nhóm chính: i) cung cấp; ii) điều tiết và duy trì và iii) văn hóa, được thể hiện qua hệ thống phân loại CICES $2017^{2}$. Cụ thể hơn, K. Van der Biest [4] và Mark Everard [5] và một số tác giá khác đã đưa ra khái niệm về các nhóm dịch vụ như sau:

- Dịch vụ cung cấp là những sản phẩm từ hệ sinh thái như thực phẩm, chất xơ, nhiên liệu, nguồn gen, hóa sinh, thuốc thiên nhiên, dược liệu và nước ngọt. Độ phì nhiêu của đất trong đụn cát khá kém và do đó các nhà khoa học thường không chú ý nhiều đến DVHST cung cấp của đụn cát như cung cấp lương thực, thực phẩm.

- Dịch vụ điều tiết và duy trì là những lợi ích từ các quá trình điều tiết và duy trì giá trị của hệ sinh thái như điều hòa khí hậu và chất lượng không khí, hấp thụ và lưu trữ carbon, hạn chế tác động của các hiện tượng cực đoan (lũ lụt, hạn hán, bão,...), lọc sạch nước, chống xói lở và duy trì độ màu của đất, thụ phấn và kiếm soát sinh học. Các DVHST điều tiết của đụn cát phổ biến như điều tiết khí hậu hoặc chất lượng không khí, đặc biệt là nguy cơ tự nhiên và chống xói mòn hệ sinh thái đụn cát đã thu hút sự chú ý của nhiều nhà khoa học [6].

- Dịch vụ văn hóa là lợi ích phi vật chất từ hệ sinh thái như bảo đảm sức khỏe thể chất, làm giàu đời sống tinh thần, phát triển nhận thức, sự suy nghĩ, giá trị giải trí, du lịch sinh thái, giá trị thẩm mĩ, cảm hứng văn hóa, nghệ thuật và thiết kế, trải nghiệm tâm linh và bản sắc địa phương. Trong hệ sinh thái đụn cát, sáu loại DVHST văn hóa thường được chú ý: i) giải trí và du lịch, ii) thẩm mỹ cảnh quan, iii) hệ thống tri thức, iv) di sản văn hóa, v) bản sắc khu vực và vi) di sản thiên nhiên [7].

\subsection{Phân loại đụn cát ven biển Sơn Trà-Tam Kỳ}

Phân loại đụn cát thường dựa trên sự khác biệt về đặc điểm môi trường, màu cát, tuổi địa chất và độ che phủ của đất $[8,9]$. Trong nghiên cứu này, đặc điểm môi trường và tuổi địa chất được phân tích, nhận dạng qua đặc điểm địa mạo đụn cát. Cấu trúc ngang của dải ven biển Sơn Trà

\footnotetext{
${ }^{2}$ https://cices.eu/
} 
- Tam Kỳ theo hướng từ bờ vào đất liền gồm 6 kiểu đụn cát từ phôi thai đến trưởng thành: i) đụn cát phôi thai; ii) đụn cát tiền tiêu; iii) đụn cát vàng; iv) đụn cát xám; v) đụn cát trắng; vi) đụn cát nâu (Hình 1). Các đụn cát đều có nguồn gốc từ biển, được gió tái tạo, có tuổi cổ dần từ phía bờ (Holocen muộn) về phía lục địa (Holocen giữa, Pleistocen muộn). Có sự phân hóa các thế hệ đụn cát ở phía bắc và nam sông Thu Bồn. Trên dải ven biển từ thành phố Hội An đến phía nam Sơn Trà chỉ có bốn loại hình đụn cát từ i) đến iv); trên dải ven biển từ Duy Xuyên đến Tam Kỳ thì có đầy đủ sáu loại hình đụn cát từ i) đến vi).

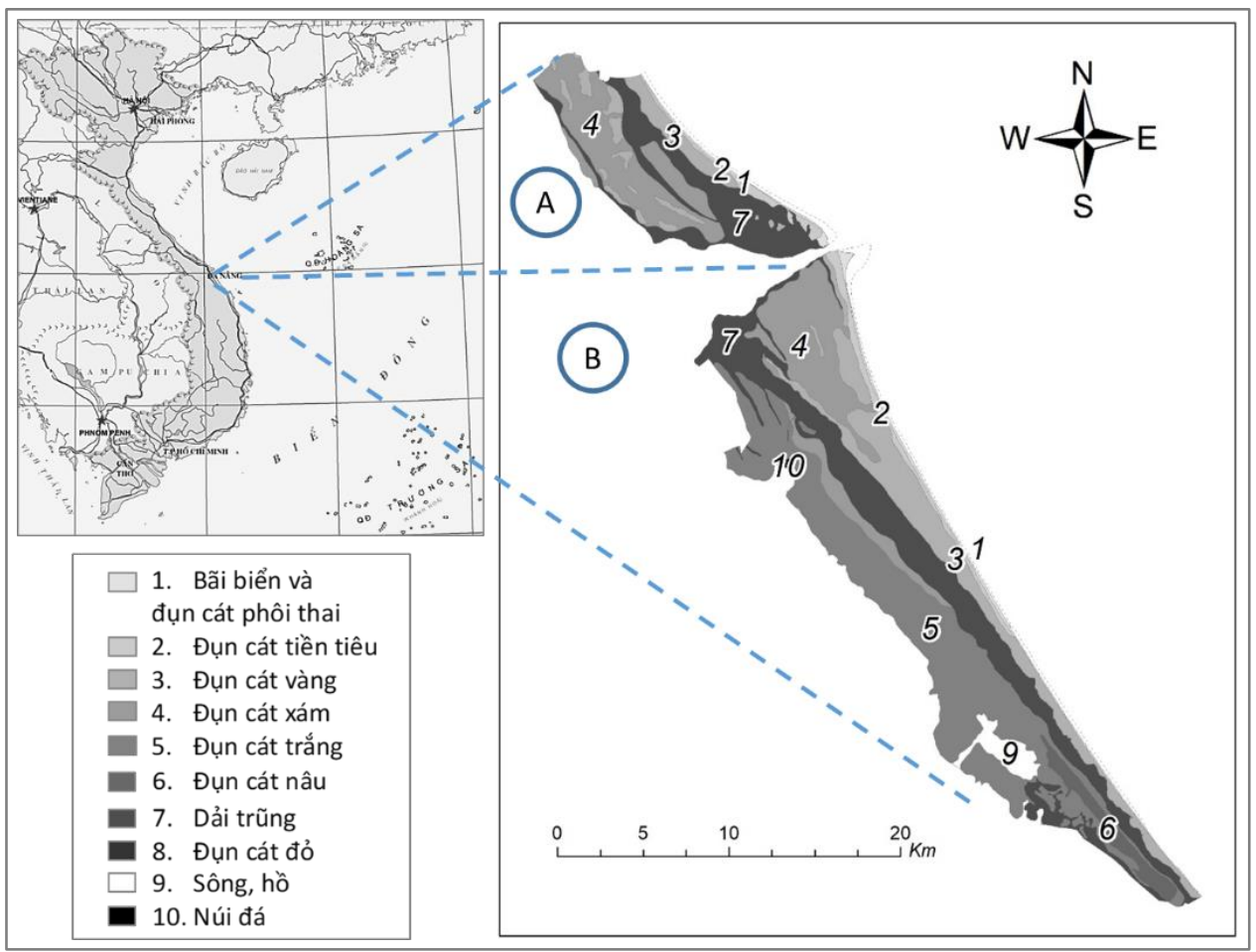

Hình 1. Sơ đồ khu vực nghiên cứu dải ven biển nam Sơn Trà (Đà Nẵng) đến Tam Kỳ (Quảng Nam).

Các đụn cát phôi thai và đụn cát tiền tiêu được phân bố không đồng nhất dọc theo các bãi biển. Trong khi các đụn cát phôi thai thường được hình thành và phá hủy hàng năm do ảnh hưởng của sóng và gió thì các đụn cát tiền tiêu đã được liên kết với nhau, kéo dài liên tục từ vài trăm đến vài nghìn mét dọc theo bờ biển, có thể gọi chúng là các "đê cát thiên nhiên". Các đụn cát tiền tiêu có độ cao từ $5-20 \mathrm{~m}$, rộng 50 - 150 $\mathrm{m}$, khi được phủ bởi thực vật sẽ đóng vai trò quan trọng trong bảo vệ bờ biển. Ngoài thảm thực vật tự nhiên như cây bụi, ở một số nơi, trên đụn cát này đã được trồng rừng, chủ yếu là phi lao. Trong các chiến lược quốc gia và địa phương đối với việc quản lý bền vững các khu vực ven biển, phôi (đụn cát phôi thai) và phôi trước (đụn cát tiền tiêu) đóng vai trò quan trọng để ngăn chặn bão, nước biển dâng và xói lở bờ biển [1] và cần được bảo vệ để duy trì giá trị dịch vụ hệ sinh thái. Do các bãi biển, đụn cát phôi thai và đụn cát tiền tiêu có chiều ngang khá nhỏ (thường không quá 200 $\mathrm{m})$ nên trong nghiên cứu này, chúng được hợp nhất để đánh giá.

Đụn cát vàng được hình thành trong thời kỳ biển thoái Holocen muộn. Những đụn cát này thường không chịu tác động của sóng biển, nhưng bị ảnh hưởng mạnh bởi gió. Độ cao tuyệt đối của đụn cát vàng dao động từ 10 đến $40 \mathrm{~m}$ và chiều rộng của chúng dao động từ 2 đến $7 \mathrm{~km}$. Trong gần 20 năm qua, các tỉnh ven biển đã nhận 
được khá nhiều kinh phí từ các dự án quốc gia để trồng mới và bảo vệ rừng (gần 3 triệu ha kể từ năm 2002) ở đụn cát vàng [10]. Tuy nhiên, do điều kiện khí hậu nóng và khô, thiếu nước và tác động mạnh từ các cơn bão nhiệt đới, mật độ che phủ của rừng phòng hộ không đồng nhất. Do đó, các nhà quản lý đã phân biệt giữa rừng sản xuất được chứng nhận và được đặc trưng bởi mật độ che phủ cao với rừng bảo vệ không chắc chắn, có đặc điểm là mật độ che phủ thấp hơn. Tuy nhiên, hệ sinh thái đụn vàng có thể cung cấp một lượng lớn giá trị thẩm mỹ cảnh quan và phù hợp cho phát triển du lịch.

Đụn cát xám có diện phân bố khá rộng rãi dọc ven biển Sơn Trà - Tam Kỳ, trầm tích của đụn cát được hình thành trong thời kỳ biển tiến Flandrian, cực đại vào Holocen giữa. Đụn cát này hiện không chịu tác động bởi sóng và ít bị ảnh hưởng bởi gió. Đụn cát xám có độ cao trung bình từ 4 đến $8 \mathrm{~m}$, chiều rộng trung bình từ 2 đến $5 \mathrm{~km}$ và kéo dài hàng chục kilomet, điển hình là đụn cát kéo dài từ phía nam bán đảo Sơn Trà, qua Ngũ Hành Sơn tới thành phố Hội An. Các khu đô thị mới ở Sơn Trà, Ngũ Hành Sơn, thành phố Hội An có quy mô khác nhau đã được phát triển trên các đụn cát này. Người dân bản địa đã định cư lâu đời trên các đụn cát xám với các hoạt động nông nghiệp như trồng cây ăn quả và rau, màu. Những dải trũng giữa các đụn cát xám được sử dụng để trồng lúa nước.

Đụn cát trắng tuổi cuối Pleistocene muộn phân bố chủ yếu ở phía tây sông Trường Giang, có độ cao trung bình 8 - $12 \mathrm{~m}$, kéo dài hàng chục kilomet từ nam sông Thu Bồn tới đông Tam Kỳ.

Bảng 1. Phân loại các đụn cát ven biển (Nguồn: theo các tác giả)

\begin{tabular}{|c|c|c|c|c|c|}
\hline $\begin{array}{c}\text { Tuổi địa } \\
\text { chất }\end{array}$ & [11] & {$[12]$} & [13] & {$[14]$} & $\begin{array}{l}\text { Thuật ngữ được } \\
\text { dùng trong bài báo }\end{array}$ \\
\hline Hiện đại & $\begin{array}{l}\text { Đụn trẻ nhất (The } \\
\text { Strand Line) }\end{array}$ & - & $\begin{array}{l}\text { Bãi biển và đụn } \\
\text { cát hiện đại }\end{array}$ & - & $\begin{array}{c}\text { Bãi biển và đụn } \\
\text { phôi thai }\end{array}$ \\
\hline \multirow{2}{*}{$\begin{array}{l}\text { Holocen } \\
\text { muộn }\end{array}$} & $\begin{array}{c}\text { Đụn phôi thai (Embryo } \\
\text { Dunes) }\end{array}$ & \multirow{2}{*}{$\begin{array}{l}\text { Đụn cát } \\
\text { vàng nhạt }\end{array}$} & \multirow{2}{*}{$\begin{array}{c}\text { Đụn cát vàng } \\
\text { pha }\end{array}$} & \multirow{2}{*}{-} & Đụn cát tiền tiêu \\
\hline & $\begin{array}{c}\text { Đụn di động (Fore } \\
\text { Dunes) }\end{array}$ & & & & Đụn cát vàng \\
\hline $\begin{array}{l}\text { Holocen } \\
\text { giữa }\end{array}$ & & $\begin{array}{l}\text { Đụn cát } \\
\text { trắng }\end{array}$ & Đụn cát trắng & $\begin{array}{l}\text { Đụn cát } \\
\text { vàng nhạt }\end{array}$ & Đụn cát xám \\
\hline $\begin{array}{l}\text { Holocen } \\
\text { sớm }\end{array}$ & $\begin{array}{c}\text { Đụn cát bán cố định } \\
\text { (Semi-stabilised dunes) }\end{array}$ & - & - & $\begin{array}{c}\text { Đụn cát xám } \\
\text { nâu }\end{array}$ & - \\
\hline $\begin{array}{l}\text { Pleistocen } \\
\text { muộn }\end{array}$ & $\begin{array}{l}\text { Đụn cát ổn định } \\
\text { (Stabilised dunes) }\end{array}$ & $\begin{array}{c}\text { Đụn cát } \\
\text { vàng nghệ }\end{array}$ & Đụn cát vàng & $\begin{array}{l}\text { Đụn cát } \\
\text { trắng }\end{array}$ & Đụn cát trắng \\
\hline \multirow{4}{*}{$\begin{array}{l}\text { Pleistocen } \\
\text { giữa - } \\
\text { muộn }\end{array}$} & $\begin{array}{c}\text { Đoạn đụn trũng (Dune } \\
\text { Slack) }\end{array}$ & - & - & $\begin{array}{l}\text { Đụn cát đỏ } \\
\text { rượu vang }\end{array}$ & Đụn cát nâu \\
\hline & $\begin{array}{l}\text { Đụn cây bụi (Dune } \\
\text { Scrub) }\end{array}$ & - & Đụn cát đỏ & $\begin{array}{c}\text { Đụn cát đỏ } \\
\text { đậm }\end{array}$ & Đụn cát đỏ \\
\hline & $\begin{array}{l}\text { Đụn cây Thạch nam } \\
\text { (Dune Heath) }\end{array}$ & - & - & - & - \\
\hline & $\begin{array}{c}\text { Đụn cây Thạch nam } \\
\text { (Dune Heath) }\end{array}$ & - & - & - & - \\
\hline
\end{tabular}

Trầm tích cát biển được hình thành trong thời kỳ biển tiến Pleistocen muộn bị tác động mạnh trong thời kỳ biển thoái cuối Pleistocen muộn, khi mực nước biển thấp hơn ngày nay khoảng $100 \mathrm{~m}$ và điều kiện khí hậu khô, tạo nên màu trắng tinh khiết. Gốc xói mòn hạ thấp khiến các đụn cát bị xâm thực, tạo các máng trũng sâu. Các máng này bị chìm ngập trong thời kỳ biển tiến cực đại vào Holocen giữa với cảnh quan đầm lầy, vũng vịnh hẹp, hiện được sử dụng cho trồng lúa, 
màu. Các đụn cát trắng có địa hình cao, khá phẳng, song hiện chưa được sử dụng cho phát triển nông lâm nghiệp. Các rừng trồng với cây phi lao, cây điều đểu kém phát triển do dinh dưỡng và kém ẩm của trầm tích. Ngoài việc sử dụng đất nông nghiệp và lâm nghiệp, cát trắng tinh khiết trên các đụn cát này còn được sử dụng làm vật liệu xây dựng, đặc biệt là nguyên liệu cho sản xuất thủy tinh.

Các đụn cát nâu phân bố trên diện tích không lớn ở phía đông nam Tam Kỳ tỉnh Quảng Nam. Sự hình thành trầm tích cát của hệ sinh thái này có khoảng thời gian cổ hơn đụn cát trắng và đã tạo ra những đụn cát có chiều cao $20-30 \mathrm{~m}$. Người dân bản địa khó có thể định cư ở khu vực đụn cát nâu, vì nước ngầm chỉ có thể được khai thác ở các lớp đất sâu. Hầu hết các khu vực đã được sử dụng để phát triển rừng phòng hộ, mặc dù hiện tại diện tích rừng vẫn còn thưa thớt.

Các đụn cát đỏ phân bố chủ yếu ở dải ven biển Bình Thuận - Ninh Thuận, trong phạm vi khu vực có điều kiện khí hậu khô nóng nhất Việt Nam. Trong phạm vi vùng bờ Sơn Trà - Tam Kỳ chưa phát hiện thành tạo này.

\section{Phương pháp đánh giá dịch vụ hệ sinh thái đụn cát}

3.1. Phuoong pháp kế thù̀a, phân tích, đánh giá tổng hơp tài liệu, điều tra và khảo sát thưc địa

Đây là phương pháp truyền thống và cũng bắt buộc đối với các cuộc nghiên cứu địa mạo nhằm phát hiện các đặc trưng địa mạo của vùng, kiểm tra và bổ sung thêm các tài liệu đã có hoặc đi sâu nghiên cứu thêm một số vấn đề hay ý tưởng mới. Đồng thời, toàn bộ tài liệu thống kê cấp quận, thị xã, thành phố thuộc tỉnh (Hội An) trong khu vực nghiên cứu được cập nhật đến năm 2019. Nhóm nghiên cứu đã tiến hành 02 đợt khảo sát thực địa tại 3 khu vực trọng điểm trong khu vực nghiên cứu gồm: khu vực Sơn Trà, Cửa Đại và Tam Kỳ từ 2019 đến $2 / 2020$. Kết quả của các đợt khảo sát thực địa là những tài liệu, ảnh chụp, mô tả, cấu tạo địa hình, đặc điểm thành phần vật chất và động lực phát triển địa hình, hiện trạng sử dụng đất trên các đụn cát khác nhau. Khảo sát thực địa cũng có mục tiêu kiểm chứng kết quả đánh giá, làm rõ hiện trạng xói lở bờ biển và vai trò của các hệ sinh thái đụn cát trong giảm thiểu thiệt hại của tác động này. Các kết quả khảo sát cũng cung cấp tài liệu cho việc tìm hiểu, đánh giá sự bền vững theo thời gian của hoạt động sử dụng đất trên các đụn cát tại khu vực nghiên cứu.

\subsection{Phuơng pháp phân tích hệ thông tin địa lý}

Trong những năm gần đây, áp dụng công nghệ viê̂n thám và GIS đã giải quyết được nhiều vẩn đề về địa mạo. Phương pháp này sử dụng loại bản đồ chuyên đề và phần mềm ArcGIS để tính toán, phân tích và quản lý số liệu.

\subsection{Phuoong pháp định lượng DVHST trên cơ sở tham vấn chuyên gia}

Dựa trên phương pháp phân tích bán định lượng DVHST được đề xuất bởi $\mathrm{B}$. Burkhard và F. Müller [15,16], một ma trận DVHST mới được thành lập bao gồm 5 loại dịch vụ cung cấp, 5 loại dịch vụ điều tiết và duy trì, và 6 loại dịch vụ văn hóa trong hệ sinh thái đụn cát. Ma trận đánh giá giá trị DVHST được nhóm tác giả đánh giá sơ bộ trước khi gửi tới 21 chuyên gia liên ngành để xem xét. Trong đó, 22 loại hình sử dụng đất (được đặt tên bởi MONRE) được đặt ở trục đứng, trong khi các loại hình DVHST được đặt trên trục hoành (Bảng 2). Tiềm năng DVHST thu được từ các loại hình sử dụng đất trên các đơn vị địa mạo đụn cát được các tác giả đánh giá tại các điểm giao cắt dao động theo thang điểm từ 0 (không cung cấp DVHST) đến 100 (cung cấp DVHST tối đa). Việc chuẩn hóa các giá trị DVHST theo một thang đo chuẩn giúp công tác so sánh giá trị DVHST dễ dàng hơn các phương pháp định lượng khác.

Trong quá trình xem xét, ma trận ban đầu được tách thành các ma trận nhỏ và gửi đến sáu nhóm chuyên gia. Tùy thuộc từng lĩnh vực chuyên môn, các ma trận nhỏ được phân chia theo các nhóm: đô thị, nông nghiệp, lâm nghiệp, địa mạo, văn hóa và sinh thái. Ví dụ, một ma trận bao gồm sáu DVHST văn hóa đã được gửi cho các nhà khoa học có kinh nghiệm trong các lĩnh vực khoa học xã hội và nhân văn; trong khi ma trận bao gồm tất cả DVHST thu được từ đất nông 
nghiệp được gửi đến các nhà khoa học trong lĩnh vực nông nghiệp. Các nhà khoa học thuộc Đại học Khoa học Tự nhiên (Hà Nội), Đại học Kiel (CHLB Đức), Viện Hàn lâm Khoa học Việt Nam (VASS), Viện Việt Nam học và Khoa học Phát triển (IVIDES), Viện Nghiên cứu Lúa gạo Quốc tế (IRRI) là những người tham gia chính trong bước này. Các nhà khoa học được yêu cầu kiểm tra toàn ma trận được gửi. Họ có thể bổ sung thêm hoặc thay đổi các loại hình sử dụng đất và DVHST ven biển còn thiếu hoặc sai. Ở cuối bước này, tất cả các thay đổi từ người đánh giá được kết hợp vào một ma trận để tính toán các giá trị cuối cùng. Nếu chênh lệch giữa các giá trị từ người đánh giá là từ 20 đến 40 thì giá trị trung bình được lấy làm giá trị cuối cùng. Nếu chênh lệch cao hơn 40 , phản hồi tiếp theo từ các nhà khoa học tương ứng sẽ là cơ sở để chọn giá trị cuối cùng. Giá trị DVHST sẽ được tính toán trên toàn khu vực nghiên cứu và tại từng loại đơn vị địa mạo đụn cát khác nhau trong các năm 2010 và 2020 theo công thức: $\mathrm{ESV}=\sum W_{i} \cdot S_{j}$; trong đó, "ESV" là giá trị DVHST, "Wi" là trọng số tiềm năng cung cấp DVHST "i", và "Sj" là diện tích của loại hình sử dụng đất "j”. Đây là kết quả quan trọng để đánh giá sự biến đổi chất lượng hệ sinh thái trong thời đoạn 10 năm.

\section{Kết quả và thảo luận}

4.1. Ma trận đánh giá tiềm năng cung cấp DVHST đụn cát ven biển

Với sự tham vấn của 21 chuyên gia trong và ngoài nước, ma trận đánh giá tiềm năng cung cấp DVHST đụn cát ven biển Sơn Trà - Tam Kỳ được trình bày ở bảng 2,3 và 4 . Các giá trị DVHST của các hệ sinh thái này được đánh giá từ mức thấp đến cao; tương ứng với giá trị từ 5 đến 95 (Bảng 3 và 4). Ma trận được thành lập với quan điểm là không có hệ sinh thái nào hoàn toàn không cung cấp (giá trị 0 ) hoặc hoàn toàn cung cấp (giá trị 100) cho bất kỳ DVHST nào. Ma trận này là nền tảng quan trọng để phân tích tiềm năng cung cấp DVHST đụn cát ven biển khác nhau ở các bước sau.

Trong nghiên cứu này, ma trận dựa trên các chuyên gia mới đã kế thừa ý tưởng từ các ma trận DVHST hiện có được phát triển trước đó bởi Burkhard và Kandziora $[15,17]$, và được điều chỉnh phù hợp với điều kiện thực tế ở Việt Nam, cũng như cụ thể tại khu vực nghiên cứu. Thay vì sử dụng một dải từ 0 đến 5 như trong các nghiên cứu trước, một dải điểm từ $0-100$ đã được sử dụng. Một mặt, các chuyên gia có nhiều lựa chọn hơn để cung cấp điểm số tương ứng với các DVHST. Mặt khác, lợi ích từ hệ sinh thái sẽ được hiểu chi tiết hơn.

Bảng 2. Các hệ sinh thái được đưa vào đánh giá chất lượng DVHST đụn cát

\begin{tabular}{|c|l|c|l|c|l|}
\hline STT & \multicolumn{1}{|c|}{ Tên hệ sinh thái } & STT & \multicolumn{1}{|c|}{ Tên hệ sinh thái } & STT & \multicolumn{1}{|c|}{ Tên hệ sinh thái } \\
\hline 1 & Đất ở đô thị & 8 & Cây công nghiệp lâu năm & 15 & Đất trồng lúa khác ("còn lại") \\
\hline 2 & Đất ở nông thôn & 9 & Cây lâu năm khác & 16 & Đất trống chưa sử dụng \\
\hline 3 & Đất chuyên dụng & 10 & Đất trồng rừng sản xuất & 17 & Đất làm muối \\
\hline 4 & Đất nghĩa địa, nghĩa trang & 11 & Đất có trồng rừng sản xuất & 18 & Đụn cát tiền tiêu \\
\hline 5 & Đất trống & 12 & Rừng trồng phòng hộ & 19 & Bãi biển tự nhiên \\
\hline 6 & Đất trồng cây hàng năm & 13 & $\begin{array}{l}\text { Đất có rừng trồng phòng } \\
\text { hộ }\end{array}$ & 20 & Nuôi trồng thủy sản \\
\hline 7 & Đất trồng cây ăn quả & 14 & Chuyên canh lúa & 21 & Sông, kênh rạch, hồ nước \\
\hline
\end{tabular}


Bảng 3. Kết quả đánh giá tiềm năng cung cấp DVHST cho các hệ sinh thái đất ở và đất rừng với sự tham gia của 21 nhà khoa học trong nước và quốc tế*

\begin{tabular}{|c|c|c|c|c|c|c|c|c|c|c|c|c|c|c|}
\hline \multirow{2}{*}{$\begin{array}{l}\text { DV } \\
\text { HST }\end{array}$} & \multirow{2}{*}{ Hệ sinh thái } & \multicolumn{5}{|c|}{ Đất ở và sinh hoạt } & \multicolumn{8}{|c|}{ Đất rừng } \\
\hline & & (1) & (2) & (3) & (4) & (5) & (6) & (7) & (8) & (9) & (10) & (11) & (12) & (13) \\
\hline \multirow{5}{*}{ 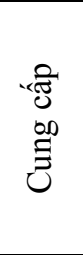 } & Cây trồng & 30 & 50 & 5 & 5 & 5 & 70 & 70 & 5 & 5 & 5 & 5 & 5 & 5 \\
\hline & Chăn nuôi & 20 & 40 & 5 & 5 & 20 & 10 & 20 & 20 & 20 & 30 & 20 & 10 & 10 \\
\hline & Lấy gỗ & 20 & 20 & 10 & 5 & 5 & 5 & 10 & 30 & 70 & 50 & 90 & 5 & 5 \\
\hline & Cá và thủy - hải sản & 5 & 10 & 5 & 5 & 5 & 5 & 5 & 5 & 5 & 5 & 5 & 5 & 5 \\
\hline & Khai thác khoáng sản & 5 & 5 & 5 & 5 & 5 & 5 & 5 & 5 & 5 & 5 & 5 & 5 & 5 \\
\hline \multirow{6}{*}{ 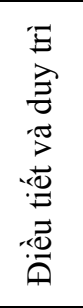 } & Tái tạo nước ngầm & 10 & 10 & 10 & 10 & 10 & 40 & 50 & 70 & 90 & 50 & 90 & 50 & 90 \\
\hline & Khí hậu địa phương & 20 & 30 & 5 & 30 & 10 & 20 & 30 & 60 & 70 & 20 & 80 & 40 & 90 \\
\hline & Khí hậu toàn cầu & 20 & 30 & 10 & 20 & 5 & 20 & 30 & 60 & 70 & 30 & 80 & 50 & 90 \\
\hline & Chất lượng không khí & 10 & 30 & 5 & 30 & 20 & 20 & 40 & 60 & 70 & 10 & 80 & 30 & 90 \\
\hline & Quá trình thổi mòn & 10 & 10 & 5 & 10 & 5 & 20 & 40 & 40 & 80 & 10 & 90 & 30 & 90 \\
\hline & Sạt lở bờ biển & 20 & 10 & 10 & 10 & 5 & 20 & 40 & 60 & 80 & 10 & 90 & 30 & 90 \\
\hline \multirow{6}{*}{ 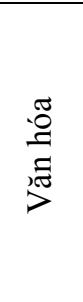 } & Du lịch và giải trí & 30 & 50 & 5 & 5 & 5 & 50 & 50 & 60 & 90 & 40 & 90 & 50 & 90 \\
\hline & Cảnh quan đặc sắc & 30 & 40 & 5 & 10 & 5 & 50 & 50 & 50 & 70 & 40 & 80 & 50 & 90 \\
\hline & Hệ kiến thức & 40 & 40 & 10 & 20 & 5 & 60 & 60 & 50 & 80 & 30 & 80 & 40 & 90 \\
\hline & Di sản văn hóa & 40 & 60 & 10 & 30 & 5 & 50 & 50 & 50 & 70 & 30 & 70 & 40 & 70 \\
\hline & Đặc trưng vùng miền & 50 & 60 & 10 & 40 & 10 & 60 & 60 & 50 & 80 & 30 & 80 & 40 & 90 \\
\hline & Di sản tự nhiên & 20 & 40 & 5 & 30 & 5 & 30 & 40 & 70 & 70 & 70 & 80 & 80 & 90 \\
\hline
\end{tabular}

*Giá trị từ (1) đến (13) là các hệ sinh thái được giải thích trong Bảng 2.

Việc sử dụng dữ liệu lớp phủ/sử dụng đất làm đại diện cho đánh giá DVHST sẽ làm đơn giản hóa việc phân tích giá trị của từng hệ sinh thái. Với một số loại DVHST cung cấp, việc sử dụng dữ liệu lớp phủ/sử dụng đất làm cho mối quan hệ của loại dịch vụ trở nên đơn giản và chính xác, ví dụ lương thực/chất xơ được cung cấp bởi các khu vực nông nghiệp, gỗ từ rừng, nước từ các vùng nước. Mặc dù vậy, bằng dữ liệu này, việc đánh giá những DVHST khác như điều tiết và văn hóa thường phức tạp hơn và cần phải dựa trên sự tương tác của các loại hệ sinh thái/sử dụng đất/lớp phủ đất khác nhau.

4.2. Mức độ cung cấp DVHST đụn cát dải ven biển Sơn Trà - Tam Kỳ

Khả năng cung cấp DVHST khác nhau giữa bảy loại hệ sinh thái đụn cát được thể hiện ở Hình 2. Các đụn cát xám có giá trị DVHST điều tiết, duy trì và văn hóa thấp nhất so với các đụn cát còn lại. Đặc biệt, giá trị của các DVHST điều tiết và duy trì tại các đụn cát vàng và nâu đạt rất cao, hơn 36.000. Giá trị này cao hơn hẳn giá trị DVHST của bốn nhóm đụn cát phôi thai, tiền tiêu, xám và trắng. Liên quan tới DVHST văn hóa, các đụn cát phôi thai/tiền tiêu, trắng và vàng có giá trị gần như nhau, dao động từ 29.000 đến 32.000. Liên quan tới DVHST cung cấp, các hệ sinh thái đụn cát cung cấp ở mức đồng đều, khoảng từ 10.000 đến 12.000 ; trong khi riêng đụn cát tiền tiêu/phôi thai có giá trị cao nhất, đạt gần 18.000. Những phân tích trên phản ánh rõ nét tầm quan trọng trong cung cấp DVHST của các đụn cát ngoài cùng, giáp biển.

Việc thiếu đi bất kỳ hệ sinh thái tự nhiên nào trên các đụn cát chưa trưởng thành đều sẽ dẫn đến sự suy giảm giá trị DVHST của các đụn cát bên trong đất liền. 
Bảng 4. Kết quả đánh giá tiềm năng cung cấp DVHST cho hệ sinh thái nông nghiệp và đất ven biển với sự tham gia của 21 nhà khoa học trong nước và quốc tế*

\begin{tabular}{|c|c|c|c|c|c|c|c|c|c|}
\hline \multirow{2}{*}{$\begin{array}{l}\text { DV } \\
\text { HST }\end{array}$} & \multirow{2}{*}{ Hệ sinh thái } & \multicolumn{3}{|c|}{ Đất nông nghiệp } & \multicolumn{5}{|c|}{ Đất ven biển } \\
\hline & & (14) & (15) & $(16)$ & (17) & (18) & (19) & (20) & (21) \\
\hline \multirow{5}{*}{$\begin{array}{l}\text { శ్లి } \\
\text { क. } \\
\Xi \\
\Xi\end{array}$} & Cây trồng & 90 & 80 & 40 & 5 & 5 & 5 & 10 & 5 \\
\hline & Chăn nuôi & 5 & 50 & 80 & 5 & 5 & 5 & 5 & 5 \\
\hline & Lấy gỗ & 5 & 20 & 5 & 5 & 5 & 5 & 5 & 5 \\
\hline & Cá và thủy - hải sản & 5 & 5 & 5 & 30 & 5 & 5 & 90 & 30 \\
\hline & Khai thác khoáng sản & 5 & 5 & 5 & 90 & 5 & 10 & 5 & 10 \\
\hline \multirow{6}{*}{ 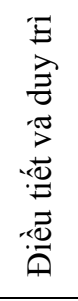 } & Tái tạo nước ngầm & 60 & 50 & 70 & 60 & 60 & 10 & 30 & 90 \\
\hline & Khí hậu địa phương & 40 & 40 & 40 & 10 & 20 & 5 & 30 & 70 \\
\hline & Khí hậu toàn cầu & 40 & 50 & 80 & 5 & 30 & 20 & 20 & 40 \\
\hline & Chất lượng không khí & 20 & 30 & 20 & 30 & 10 & 5 & 10 & 10 \\
\hline & Quá trình thổi mòn & 20 & 50 & 70 & 5 & 10 & 5 & 5 & 5 \\
\hline & Sạt lở bờ biển & 20 & 50 & 70 & 5 & 5 & 5 & 5 & 20 \\
\hline \multirow{6}{*}{ 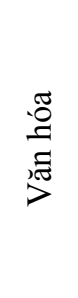 } & Du lịch và giải trí & 40 & 60 & 30 & 30 & 70 & 80 & 50 & 90 \\
\hline & Cảnh quan đặc sắc & 50 & 50 & 30 & 20 & 70 & 70 & 40 & 90 \\
\hline & Hệ kiến thức & 40 & 50 & 20 & 40 & 60 & 60 & 30 & 70 \\
\hline & Di sản văn hóa & 70 & 50 & 50 & 40 & 60 & 70 & 40 & 80 \\
\hline & Đặc trưng vùng miền & 70 & 50 & 20 & 70 & 60 & 70 & 30 & 80 \\
\hline & Di sản tự nhiên & 30 & 60 & 40 & 20 & 80 & 70 & 20 & 80 \\
\hline
\end{tabular}

*Giá trị từ (14) đến (21) là các hệ sinh thái được giải thích trong Bảng 2.

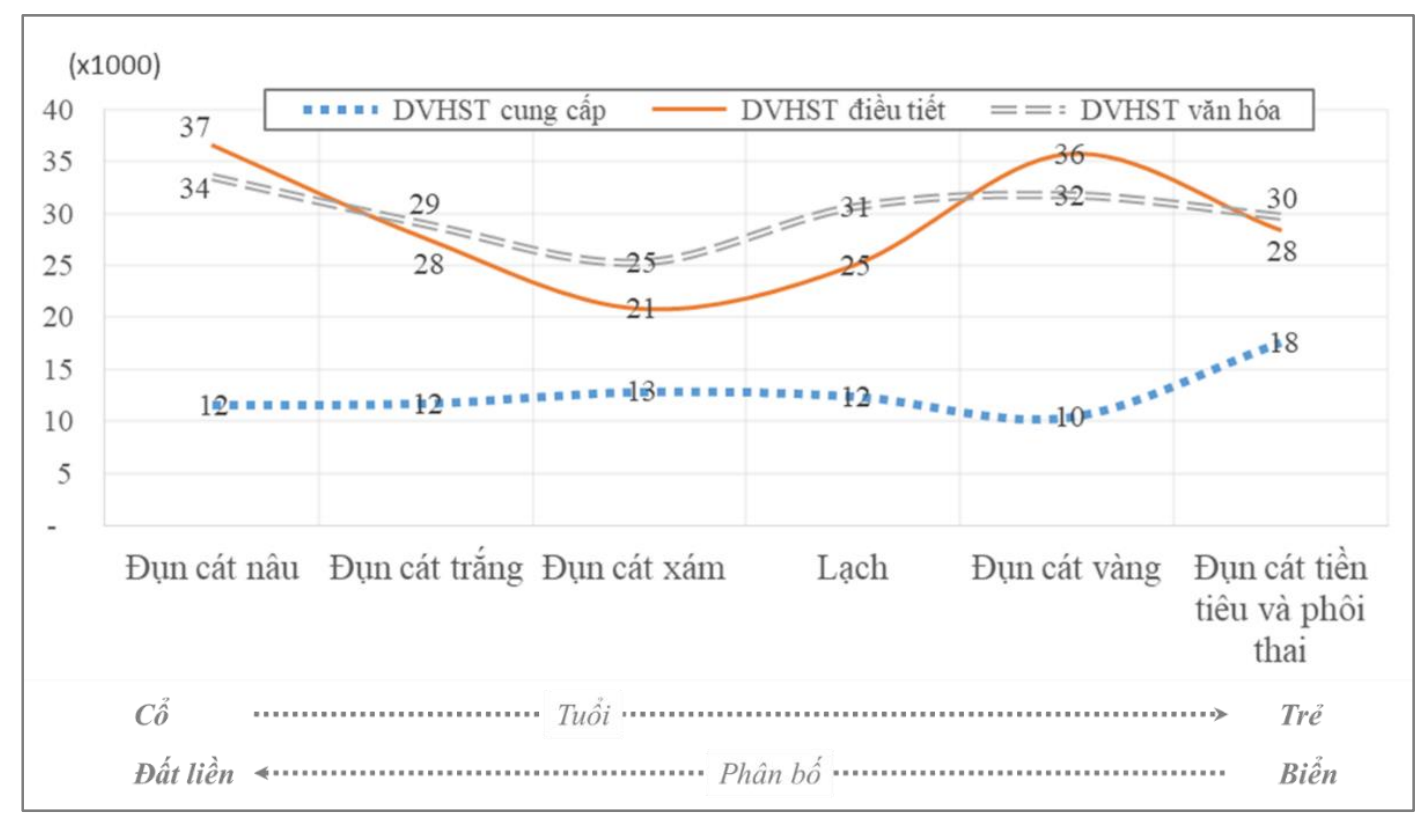

Hình 2. Đánh giá tổng thể phân phối DVHST giữa các đụn cát khu vực nghiên cứu dựa trên bảng ma trận cung cấp DVHST. 
Chức năng điều tiết sạt lở bờ biển, nước biển dâng của các đụn cát này được gia tăng nếu có sự mở rộng của hệ thống rừng phòng hộ dọc bờ biển, đặc biệt là các vùng bờ bồi tụ ở Duy Xuyên, tỉnh Quảng Nam. Ngược lại, đối với các bờ biển bị sạt lở, chẳng hạn như ở khu vực Cửa Đại (thành phố Hội An), Cửa ở (Tam Kỳ), các cồn cát và bãi biển bị thu hẹp đáng kể, thậm chí nhiều nơi không còn bãi biển, sóng biển trong bão, gió mùa đông bắc kết hợp triều cường đã tác động tới các công trình xây dựng, cụm cư dân ở phía trong, gây thiệt hại nặng nề. Cồn cát phôi thai và tiền tiêu là vùng đất đầu tiên chịu ảnh hưởng của các tai biến tự nhiên ven biển. Việc duy trì trạng thái tự nhiên của bãi biển, cồn cát phôi thai và tiền tiêu không chỉ đóng vai trò quan trọng trong điều tiết xói lở hàng năm, mà còn bảo vệ các hệ sinh thái trong đất liền khỏi tác động tiêu cực của các hiện tượng cực đoan. Các hoạt động phát triển du lịch (xây dựng cơ sở hạ tầng du lịch) ở dải ven biển Sơn Trà - Tam Kỳ cũng như nhiều khu vực ven biển khác ở Việt Nam có xu hướng mở rộng ra phía biển, dẫn đến sự suy giảm giá trị DVHST tự nhiên, chẳng hạn như khả năng chống xói lở bờ và lọc không khí [18].

Để giảm thiểu thiệt hại do sạt lở bờ biển, ứng phó biến đổi khí hậu, nước biển dâng, cần có giải pháp bảo vệ các hệ sinh thái đụn cát sát biển, như đã được nhiều quốc gia thực hiện. Một ví dụ điển hình đã được nhóm tác giả tiếp cận tại thành phố Lacanau, Pháp. Tại bờ biển có nguy cơ sạt lở bờ biển cao này, chính quyền đã chọn các giải pháp tự nhiên để ổn định bờ biển bằng cách tránh tác động của con người và nước biển dâng. Tiếp cận của người dân từ phía trong ra bãi biển được giới hạn bằng các lối mòn có trải các thanh gỗ nhỏ để không trực tiếp bước chân trên đụn cát [19]. Các giải pháp ở các nước phát triển đã giúp tối ưu hóa các quá trình bồi tụ ven biển và tránh quá trình đô thị hóa quá nhanh tác động tới hệ sinh thái đụn cát ven biển.

\subsection{Tiền năng cung cấp DVHST đụn cát tại dải ven biển Son Trà - Cửa Đại}

Sau khi phân tích tiềm năng cung cấp DVHST tại khu vực Sơn Trà - Cửa Đại, giá trị DVHST tại các quận ven biển Thành phố Đà
Nẵng thường thấp hơn hẳn so với các xã/phường ven biển Quảng Nam, đặc biệt là các DVHST điều tiết, duy trì và văn hóa. Đối với các loại hình DVHST cung cấp, sự chênh lệch này không rõ rệt.

Tại dải ven biển từ quận Sơn Trà đến quận Ngũ Hành Sơn (Đà Nẵng), các khu vực đất ven biển hầu hết được phân lô, xây dựng kín ra sát bãi biển, khiến tiềm năng cung cấp DVHST bị suy giảm nhiều. Khu vực dân cư thuộc các phường Phước Mỹ và Khuê Mỹ được lùi vào sâu từ tuyến đường ven biển, một số nơi được che chắn bởi dải rừng phòng hộ đã giúp giá trị DVHST điều tiết và duy trì được cải thiện hơn so với phường Hải Hòa.

Tại khu vực phường Hòa Hải (quận Ngũ Hành Sơn, Đà Nẵng) và phường Điện Ngọc (thị xã Điện Bàn, Quảng Nam), nhiều khu du lịch được xây dựng sát biển khiến khả năng phòng chống tai biến thiên nhiên bị suy giảm. Thêm vào đó, việc quy hoạch các khu du lịch ven biển sát nhau khiến người dân địa phương và khách du lịch gặp khó khăn trong việc tiếp cận biển, kéo theo sự suy giảm về giá trị văn hóa, phá vỡ cảnh quan tự nhiên. Mặc dù các khu du lịch được xây dựng nhằm mục đích đáp ứng nhu cầu của khách trong và ngoài nước, nhưng đó là lượng khách giới hạn và phải trả tiền. Thay vào đó, các giá trị văn hóa, cảnh quan và nhu cầu thư giãn của người dân địa phương ven biển và cộng đồng nói chung đã bị suy giảm đáng kể. Nhìn chung, khu vực này được đánh giá có giá trị DVHST văn hóa thấp nhất trong toàn khu vực nghiên cứu.

Kết quả đánh giá tiềm năng cung cấp DVHST được thể hiện trên Hình 3 cho thấy đoạn ven biển Điện Dương - Cửa Đại khả quan hơn nhiều so với đoạn Sơn Trà - Hòa Hải. Mặc dù phần phía bắc thị xã Điện Bàn (phường Điện Ngọc) có mật độ xây dựng hạ tầng du lịch khá lớn, song các phương án quy hoạch vẫn có sự hài hòa giữa thực phủ và khu xây dựng. Đoạn phía nam thị xã Điện Bàn (phường Điện Dương) hiện vẫn còn nhiều dải rừng phòng hộ trên đụn cát được bảo vệ, phía trong là quần cư nông thôn và đất nông nghiệp. Điều đó giúp giá trị DVHST khu vực này ổn định và cao hơn đáng kể đoạn phía Sơn Trà - Hải Hòa. 


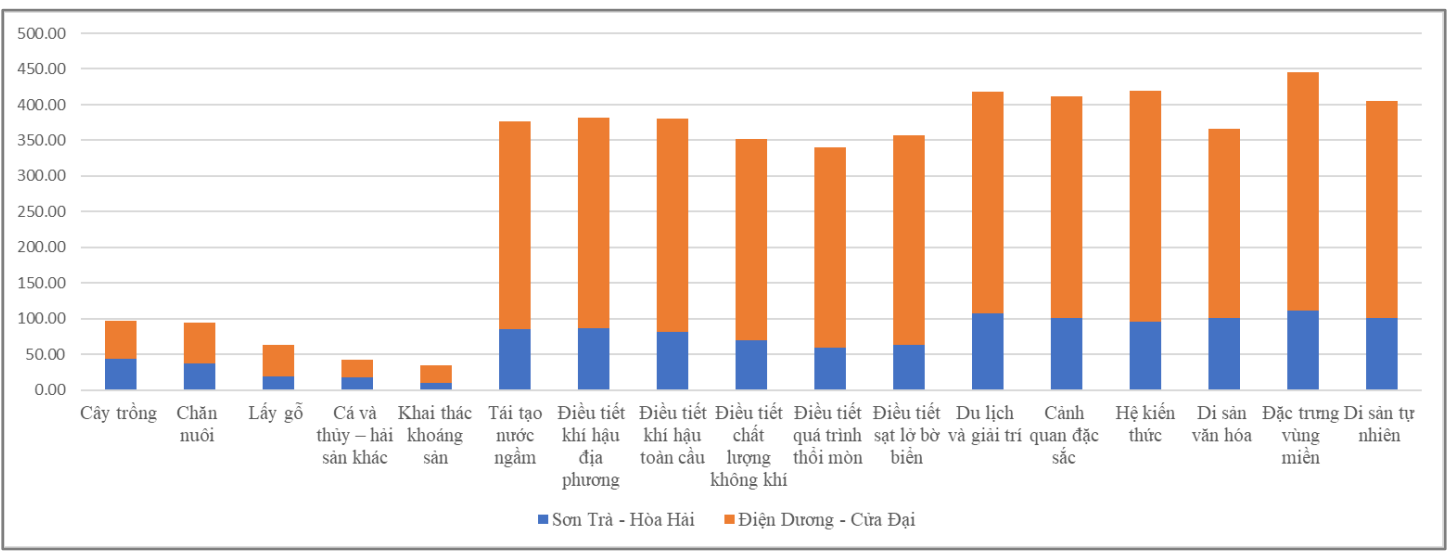

Hình 3. Chi tiết giá trị 16 loại DVHST cho 2 khu vực Sơn Trà - Hòa Hải và Điện Dương-Cửa Đại.

Kết quả so sánh tiềm năng cung cấp DVHST đụn cát ven biển giữa thành phố Đà Nẵng và tỉnh Quảng Nam cũng cho thấy các đụn cát ở Quảng Nam, đặc biệt là phía nam Cửa Đại có giá trị cao hơn. Việc bảo vệ rừng phòng hộ ven biển trên các đụn cát vàng và đụn cát tiền tiêu là hết sức cần thiết để ngăn chặn, giảm thiểu tác hại của các tai biến thiên nhiên. Việc phát triển các khu du lịch, khu dân cư trên các đụn cát ven biển sẽ làm giảm khả năng cung cấp các DVHST khác, đặc biệt là các dịch vụ gắn với quyền tiếp cận tới biển của người dân. Điều này cần được phân tích sâu hơn trong các nghiên cứu sau này. Việc phân phối sử dụng đất trong các hệ sinh thái đụn cát là cơ sở hữu ích cho các nhà quản lý hiểu hơn giá trị của DVHST ở cấp độ khu vực, qua đó có thể lựa chọn giải pháp sử dụng đất phù hợp, đạt được sự cân bằng trong cung cấp DVHST dài hạn.

\section{Kết luận}

Trên cơ sở đánh giá DVHST đụn cát ven biển Sơn Trà - Tam Kỳ, nghiên cứu đưa ra một số kết luận sau:

- Các đụn cát phôi thai và tiền tiêu là vùng đất đầu tiên chịu ảnh hưởng bởi các nguy cơ tự nhiên từ phía biển. Các đụn cát này có tiềm năng dịch vụ hệ sinh thái cao, không chỉ đóng vai trò quan trọng trong điều tiết sạt lở bờ biển mà còn có tác dụng bảo vệ các hệ sinh thái trong đất liền khỏi tác động của các hiện tượng thời tiết cực đoan liên quan tới biến đổi khí hậu, nước biển dâng.

- Do mức độ đô thị hóa và suy giảm nghiêm trọng diện tích rừng phòng hộ trên đụn cát tại dải ven biển, đoạn bờ Sơn Trà - Hòa Hải thuộc thành phố Đà Nẵng có tiềm năng cung cấp DVHST thấp hơn nhiều so với đoạn bờ Điện Dương Cửa Đại thuộc tỉnh Quảng Nam.

Nhằm quản lý tốt dải ven biển, cần có giải pháp kiên quyết trong bảo vệ các hệ sinh thái và duy trì giá trị dịch vụ hệ sinh thái đụn cát, trước tiên là định hướng mở rộng diện tích và quản lý chất lượng rừng phòng hộ trên các đụn cát tiền tiêu và phôi thai cho tăng cường chức năng điều tiết xói lở bờ biển, chống bão và nước biển dâng, bảo vệ môi trường và tăng giá trị cảnh quan ven biển khu vực Sơn Trà - Tam Kỳ nói riêng và vùng bờ cát nói chung.

\section{Lò̀i cảm ơn}

Bài báo này được hoàn thành trong khuôn khổ đề tài NCKH cấp nhà nước mã số KC.09.17/16-20. Tập thể tác giả xin chân thành cảm ơn.

\section{Tài liệu tham khảo}

[1] H.N.T. Do, Quaternary geological characteristics and underground sources in coastal lands of Quang Nam province, Hanoi University of Mining and Geology, 2016. 
[2] Millennium Ecosystem Assessment, Ecosystems and human well-being, 5/281, 2005. https:// doi.org/10.1016/B978-0-12-409548-9.09206-X.

[3] M. Potschin, R. Haines-Young, R. Fish, R. K. Turner, Routledge handbook of ecosystem services. Routledge, 2016. https://doi.org/10.4324/ 9781315775302.

[4] K. Van der Biest, L. De Nocker, S. Provoost, A. Boerema, J. Staes, P. Meire, Dune dynamics safeguard ecosystem services, Ocean Coast. Manag. 149 (2017) 148-158. https://doi.org/ 10.1016/j.ocecoaman.2017.10.005.

[5] M. Everard, L. Jones, B. Watts, Have we neglected the societal importance of sand dunes? An ecosystem services perspective, Aquat. Conserv. Mar. Freshw. Ecosyst. 20 (4) (2010) 476-487. https://doi.org/10.1002/aqc.1114.

[6] M. S. Meixler, Assessment of Hurricane Sandy damage and resulting loss in ecosystem services in a coastal-urban setting, Ecosyst. Serv. 24 (2017) 28-46. https://doi.org/10.1016/j.ecoser. 2016.12.009.

[7] U.M. Nehren, H. Thai, H. Dac, C. Raedig, S. Patricia, A. De Nehren, Chapter 18: Ecosystem Services of Coastal Dune Systems for Hazard Mitigation: Case Studies from Vietnam, Indonesia, and Chile, in: Ecosystem Services of Coastal Dune Systems for Hazard Mitigation, 2016. https://doi.org/10.1007/978-3-319-43633-318.

[8] R.G. Biel, S.D. Hacker, P. Ruggiero, N. Cohn, E. W. Seabloom, Coastal protection and conservation on sandy beaches and dunes: Context-dependent tradeoffs in ecosystem service supply, Ecosphere, 8/4, 2017. https://doi.org/10. 1002/ecs2.1791.

[9] A. Urbis, R. Povilanskas, A. Newton, Valuation of aesthetic ecosystem services of protected coastal dunes and forests, Ocean Coast. Manag., 179, 2019. https://doi.org/10.1016/j.ocecoaman. 2019.104832.

[10] L.T. Tam, Solution for tourism development in Binh Thuan province in the period of 2015-2020, J. Dev. Integr. 32 (05)(2015) 78-81.

[11] D. Holmes, The Geography of Coastal Sand Dunes. Geo Factsheet, Birmingham, 119, 2001.
[12] T. Nghi, Evolution to form coastal sand system in Central Vietnam in the interaction relationship with sea level changes in Quaternary, Proceeding of Marine Geological and Geophysical Researches, 2, 1996, pp. 130-138.

[13] L.D. An, U.D. Khanh, Geomorphology in Vietnam: Structure - Resources - Environment, Publishing of Natural and Technological Sciences, 2012.

[14] N.V. Tuan, T. Nghi, T.T. Van, N.X. Khien, Provenance, Characteristics and Paleogeographic Conditions of the Quaternary Sandy Formations in Coastal Area of Binh Thuan Province, VNU Journal of Science: Earth and Environmental Sciences 34(3) (2018) 55-70. https://doi.org/ 10.25073/2588-1094/vnuees.4267.

[15] B. Burkhard, M. Kandziora, Y. Hou, F. Müller, Ecosystem service potentials, flows and demandsconcepts for spatial localization, indication and quantification, Landscape Online, 34 (1) (2014) 1-32. https://doi.org/10.3097/LO.201434.

[16] F. Müller, Assessing ecosystem service potentials to evaluate terrestrial, coastal and marine ecosystem types in Northern Germany - An expert-based matrix approach, Ecol. Indic., 112, 2020, p. 106116. https://doi.org/10.1016/j. ecolind.2020.106116.

[17] M. Kandziora, B. Burkhard, F. Müller, Interactions of ecosystem properties, ecosystem integrity and ecosystem service indicators-A theoretical matrix exercise, Ecol. Indic. 28 (2013) 54-78. https://doi.org/10.1016/j.ecolind.2012.09.006.

[18] T. Nghi, Solutions to minimize hazards and to reform littoral sandy bars aimed to sustainable economic development in Quang Binh province, VNU J. Sci., 2 (2006) 10.

[19] C. Vinchon, Response of the Coastline to Climate Change. Specific Report for the RESPONSE Project LIFE-Environment program: Evolution of coastal risk (erosion and marine flooding) on the Aquitaine and Languedoc- Roussillon pilot regions. Final report. BRGM/RP-54718, 2006. 